\title{
Brand and consumer characteristics as drivers of behaviour towards global and local brands*
}

\author{
Srđan Šapić ${ }^{1}$, Milan Kocić², Jovana Filipović3
}

\begin{abstract}
The main purpose of this research is to determine influence of brand and consumer characteristics on consumers ' behaviour regarding purchase of global and local brands. Starting from Theory of planned behaviour and Theory of social identity several antecedents of consumers 'attitudes were researched in proposed modelquality of brands, prestige, ethnocentrism and materialism. For this purpose, sample comprising of 329 respondents was collected. Confirmatory factor analysis was used to test the validity of the model and structural equation modelling (SEM) was used to determine relationships between variables. Empirical research has shown that the factors of quality of local brands and ethnocentrism have a positive and statistically significant effect on the consumers 'attitudes towards the local brands. On the other side, brand quality, prestige and materialism have a positive effect on the attitudes of consumers towards global brands, whereas ethnocentrism has a negative effect on attitudes towards this type of brands. In addition, research has shown that the attitudes have positive influence on consumers 'behavioural intentions regarding purchase of both local and global brands and that consumers ' intentions have positive effect on actual purchase of both types of brands. The main finding of the paper implies that the characteristics of consumers and brands influence consumer behaviour in terms of purchasing aforementioned types of
\end{abstract}

* Received: 10-04-2017; accepted: 26-03-2018

1 Associate Professor, Faculty of Economics, University of Kragujevac, Liceja Kneževine Srbije 3, 34000 Kragujevac, Serbia. Scientific affiliation: international marketing, international business.Phone:+38134303 575.Fax:+38134303 516.E-mail: ssapic@kg.ac.rs.Personal web page: http://www.ekfak.kg.ac.rs/en/teaching-stuff?id=366\&idd=268.

${ }^{2}$ Associate Professor, Faculty of Economics, University of Kragujevac, Liceja Kneževine Srbije 3, 34000 Kragujevac, Serbia. Scientific affiliation: marketing. Phone: +381 34303 538. Fax: +38134303 516. E-mail: mkocic@kg.ac.rs. Personal web page: http://www.ekfak.kg.ac.rs/en/ teaching-stuff? id $=366 \& i d d=199$.

3 Teaching assistant, PhD student, Faculty of Economics, University of Kragujevac, Liceja Kneževine Srbije 3, 34000 Kragujevac, Serbia., Scientific affiliation: international marketing, international business. Phone: +38134303 530.Fax:+38134303 516.E-mail: jovanagolo@ kg.ac.rs. Personal web page: http://www.ekfak.kg.ac.rs/en/teaching-stuff?id=366\&idd=398 (corresponding author). 
brands. The conducted research has a scientific and practical contribution in terms of obtaining information about the factors that influence the consumers decisions regarding the purchase of both local and global brands.

Key words: global brand, local brand, brand quality, prestige, materialism, ethnocentrism, consumers 'attitudes and intentions

JEL classification: $M 31$

\section{Introduction}

In the last couple of decades, there have been significant changes in the international and global business environment. The modern business environment is characterized by the process of globalisation, the development of the Internet, mass media and other technologies, as well as the increasing number of mass migrations of consumers. These trends lead to the creation of the so-called global consumer culture (Alden et al., 2006; Holt et al., 2004). This culture implies the segments of consumers on a global level, who have the same or similar interests and tastes regarding the purchase and the consumption of products and services (Nijssen and Douglas, 2011). In accordance with that, the literature on marketing, starting from the 1980s onwards, has pointed out the appearance of the homogenisation of consumer needs, wishes and tastes on a global level (Levitt, 1983), as well as that international and global companies respond to this occurrence with an offer of standardized, global products and services (Keillor et al., 2001). A consequence of such an approach is the appearance and the development of global brands, which, thanks to their widespread presence, recognisability and image, generate high amounts of income and value for global companies.

There is a large number of research whose focus is on the analysis of global brands, as well as their competitors in local markets (local brands), in the literature on international marketing (e.g. Holt et al., 2004; Özsomer, 2012; Steenkamp et al., 2003; Strizhakova et al., 2011). Global brands are characterized by a widespread presence in the world market as well as by the fact that the consumers are familiar with them in a large number of markets, through the use of a standardized marketing strategy on a global level (Schuiling and Kapferer, 2004; Steenkamp et al., 2003). In many markets, global brands oppose strong local brands very often. Local brands are generally defined as those brands which are available in one country or in a narrow geographical area, even though these brands may be owned by a local, international or a global company (Schuiling and Kapferer, 2004; Dimofte et al., 2008). In conditions of pronounced competition between local and global brands, it is important to understand the antecedents of consumers 'decisions regarding the purchase of these types of brands.

By analyzing the relevant scientific literature and the results of previous research (Özsomer and Altaras, 2008; Gurhan-Canli et al., 2018), a theoretical and methodo- 
logical framework for analyzing drivers of attitudes and intentions of consumers towards the purchase of local and global brands was created. Namely, two groups of drivers have been identified, whose influence on the attitudes and intentions of the consumers is analyzed in the paper, and those are the characteristics of the brands and the characteristics of the consumers. Within the characteristics of local and global brands, the observed characteristics are the functional quality of brands, that is, quality, as well as the social value of brands, or prestige. Consumers' characteristics which are analyzed in the paper include ethnocentrism and materialism. These antecedents were chosen on the basis of their use in previous studies, conducted mostly in developed countries. Therefore, the purpose of this paper is the analysis of their influence on consumer behaviour, in the COO context in developing country, such as Serbia. Bearing in mind that Serbia is country in transition, with moderately high level of ethnocentrism (Marinković et al., 2011) and moderate level of materialistic vales (Hofstede et al., 2010, p. 143), aim of the paper was to analyse whether these variables have similar influence as they have on consumer behaviour in developed countries.

In accordance with previous statements, the aim of this research is the analysis of effects which brand and consumer characteristics have on the consumers' attitudes towards local and global brands, as well as the analysis of the effects which the attitudes have on the intentions of consumers concerning the purchase of these brands. Additionally, one of the aims of the paper is the analysis of the influence which the consumers' intentions have on the actual purchase of the aforementioned types of brands.

The main hypothesis of the paper is that brand characteristics and consumer characteristics have statistically significant impact on consumers' behaviour regarding the purchase of local and global brands.

The paper is structured into six parts. After the introductory considerations, the theoretical conceptualization of the observed factors that affect consumers' attitudes is introduced. In the next part, methodology and the conceptual model of the research, are primarily explained. Empirical data which was collected for the purpose of analyzing the impact of selected factors on consumers' behaviour are described in forth part of the paper. The analysis of the results of the empirical research, based on which the main hypothesis is tested, is presented in the fifth part. The sixth part of the paper includes the concluding considerations. At the very end of the paper, the basic limitations of the research, as well as the potential future directions in the research of the described problem, are pointed out. 


\section{Literature review}

Global brands can be found in many countries all over the world, with the same name and logo for the same product, same marketing mix and most often same positioning strategy (Schuiling and Kapferer, 2004; Yip and Hult, 2012). The most common motives for the purchase of these products are their international recognisability, widespread presence and availability of these products in numerous markets, superior quality, as well as the preference of consumers for sophisticated, modern and prestigious products (Özsomer, 2012). On the other side, local brands are created according to the unique needs and wishes of local, domestic markets and they are suited to them. In comparison with global brands, local brands imply respect and fitting into the cultural traditions of the country in which they originated, and they represent them, as well (Özsomer, 2012). These brands have their advantages, such as the perceptions of uniqueness, originality and pride of representing the local market. Local brands have traditionally benefited from a high level of awareness and close relations with the consumers in their countries. As shown by Dimofte et al. (2008), these brands not only reflect, but also help to define the character of the local market. As such, some of these brands are perceived as "local icons" in their markets to the extent to which they are connected with the symbols of culture, heritage and national identity.

Quality and reliability are the basic characteristics which international and global companies use for the successful promotion and sales of their branded products (Holt et al., 2004). From the perspective of companies, brands which are perceived as high quality brands achieve greater sales, market participation and profit (Erdem et al., 2006). In order to achieve that, companies must bear in mind that the perceived quality of global brands refers to the wishes and expectations of consumers regarding functional and practical uses of those products (Steenkamp et al., 2003). Moreover, quality, performance and reliability are some of the most significant criteria which consumers use when choosing and purchasing brands, based on which we can realize the significance of these elements for the success of companies (Özsomer, 2012; Strizhakova et al., 2008). Regarding the effects of brand quality, an important value of a brand is its role as a signal of technical advancement, stability and safety, that strengthen consumers' confidence in the brand's ability to deliver on its promise (Xie et al., 2015).

When a certain brand is perceived as a global brand, consumers will associate a higher level of quality with it because they will think that this quality is of vital importance for the achievement of world success of that given brand and its acceptance (Kapferer, 1997; Keller, 1998). Precisely for this reason, when consumers purchase global brands, they expect technologically advanced, stable, secure and reliable products (Batra and Sinha, 2000). In accordance with the previous claims, numerous previous studies have proven that quality has a positive effect on the formation of preferences towards global brands (Swoboda and Hirschmann, 2016; Alden et al., 2006; Batra 
et al., 2000; Heinberg et al., 2016; Holt et al., 2004; Özsomer, 2012; Özsomer and Altaras, 2008; Steenkamp et al., 2003; Dimofte et al., 2010; Kumar et al., 2009; Zhou and Wong, 2008), as well as on their purchase (Strizhakova et al., 2011). Similarly, research has shown that, when consumers perceive certain brands as global, then they also form perceptions that the given brands offer high value, both functional and psychological (Swoboda and Hirschmann, 2016), and that they possess a high level of credibility and a low level of risk (Keller, 1998).

However, even though local brands are generally perceived as a low quality alternative to global brands (Dimofte et al., 2008; Ger, 1999; Guo, 2013), certain authors point out that local brands can offer better quality to consumers considering that the perceptions of quality differ in certain markets and that global, standardized products do not satisfy specific needs of different markets (Ger, 1999). Some scholars have argued that perceived brand localness is helpful to increase consumers' perceptions of brand quality, because it signals a deeper understanding of local quality needs and serves as a symbol of authenticity (Ger, 1999).The claim that the quality of local brands positively influences the consumers' attitudes regarding their purchase has been analyzed in a smaller number of studies and only for specific categories of products (Özsomer, 2012), whereas no such connection has been found in other studies (Steenkamp et al., 2003; Strizhakova and Coulter, 2015). Besides, it has been proven that the perceived quality of local brands lowers the probability of purchase of global brands, since it increases the probability of purchase of local ones (Özsomer, 2012). Based on the results of previous studies, we expect that quality will have positive and statistically significant impact on the consumers' attitudes towards the purchase of local and global brands.

One of the reasons for which consumers may prefer global brands to local ones may be the more highly perceived prestige of global brands (Kapferer, 1997). In fact, Holt et al. (2004) point out that one of the main associations connected with global brands is their prestige. Overall, global brands are less available and more expensive than local alternatives, which may contribute to the creation of their prestigious reputation (Batra et al., 2000). By using branding, international companies try to give their products a certain meaning of prestige and to promote them as status symbols. On the other hand, consumers themselves purchase and use such products to improve their own status and their image in the society (Strizhakova et al., 2008). Besides, certain consumers buy global brands in order to improve their own image from the aspect of cosmopolitanism, sophistication and modernity (Friedman, 1990). Moreover, prestigious brands may provide affective benefits as a result of their enhancement of consumers' self-esteem and their perceived social superiority because such brands serve as a signal of status, wealth, and upscale taste (Kunda, 1999). In other words, by using prestigious brands, consumers could perceive themselves and be perceived by significant others in a more favourable light, which should generate favourable emotional reactions. 
Social prestige is reflected in the consumer's evaluation of increased selfconfidence and social status brought about by the possession and the use of products which belong to the category of global brands (Batra et al., 2000; Steenkamp et al., 2003). In relation to that, numerous authors point out that one of the main motivators of consumers for the purchase of global brands is the wish to improve their own social status (Holt, 2002; Thompson and Tambyah, 1999). This has been empirically proven in previous studies (Ger, 1999; Steenkamp et al., 2003; Holt et al., 2004; Zhou and Belk, 2004). By purchasing global brands consumers want to obtain products which serve for the so-called conspicuous consumption, which is particularly pronounced in developing countries, where consumers strive to have a higher status and reputation in society (Batra et al., 2000).

On the other hand, consumers can also associate local brands with a high level of prestige, because they can be unique, authentic and the so-called "icons" of national culture. Advocates of local brands believe that local brands can also benefit from higher prestige perceptions in competition against their global counterparts (Ger, 1999), stemming from their stronger connections with local culture, country, and heritage (Belk and Paun, 1993). This claim has been proven in certain studies. For example, Steenkamp et al. (2003) find a positive linkage of local iconness with brand prestige in their Korean and U.S. samples. Özsomer (2012) also reports a positive relationship between local iconness and local brands' perceived prestige in both emerging and mature markets. On the other hand, other researchers have suggested divergent results (Batra et al., 2000; Kumar et al., 2009). In accordance with previous studies, we expect that prestige will have a positive and statistically significant impact on the consumers' attitudes towards the purchase of local and global brands.

Consumer ethnocentrism is defined as a collection of beliefs concerning the appropriateness and morality of purchasing products that were made abroad (Shimp and Sharma, 1987). According to this concept, the purchase of foreign products is wrong from the perspective of ethnocentric consumers, because it has a harmful effect on the domestic economy, it causes a loss of jobs, and it represents an unpatriotic activity. Therefore, consumers who are highly ethnocentric generally decide not to purchase foreign products, because they believe that it hurts the prosperity of their own country, in a way that opting for foreign products threatens the domestic industry and causes unemployment (Verlegh, 2007). At the same time, ethnocentric consumers also want to protect their economy by purchasing domestic products (Sharma, 2011; Supphellen and Rittenburg, 2001). Consumers who mostly oppose foreign products because of their concern about the prosperity of their own country and its income are likely to observe global companies, which produce their products in several foreign locations and place their brands in many countries, as part of the total economic challenge which their country is facing, because of globalization (Alden et al., 2013). 
Consumers who are highly ethnocentric firmly refuse to buy foreign products and often criticize their friends and acquaintances for doing so. In addition, highly ethnocentric consumers are prone to having a biased assessment, so they are more susceptible to highlighting positive aspects of domestic products and reducing the value of foreign products (Netemeyer et al., 1991; Shimp and Sharma, 1987).

Ethnocentrism is the subject of numerous studies which examined its impact on the formation of evaluations and readiness for the purchase of domestic and foreign products and brands. The findings of Crane (2002) and Steenkamp et al. (2003) suggest that ethnocentric sentiments play an important role in shaping individuals' responses to global products and brands. Highly ethnocentric consumers tend to reject brands that are culturally dissimilar while favouring those that originate in their own culture (Shimp and Sharma, 1987). Furthermore, numerous studies have shown that ethnocentrism has a negative impact on the evaluation, attitudes and intentions of consumers towards foreign and global brands (Oberecker and Diamantopoulos, 2011; Schimp and Sharma, 1987; Verlegh, 2007; Klein, 2002; Klein et al., 2006; Cleveland et al., 2009; Sharma, 2011; Siamagka and Balabanis, 2015). On the other hand, the positive influence that ethnocentrism has on the attitudes and intentions of consumers towards local brands has also been proven in various studies (Balabanis and Diamantopoulos, 2004; Josiassen, 2011; Strizhakova and Coulter, 2015; Verlegh, 2007; Cleveland et al., 2009; Siamagka and Balabanis, 2015; Klein et al., 2006; Sharma, 2011; Strizhakova and Coulter, 2015). Based on the given theoretical claims and the results of previous research, we posit that ethnocentrism will have a positive and statistically significant impact on consumers' attitudes towards purchasing local brands, and negative on consumers' attitudes towards purchasing global brands.

Materialism can be defined as "a set of centrally held beliefs about the importance of possessions in one's life, which guides people's choices and conduct in a variety of situations, including, but not limited to, consumption arenas." (Richins and Dawson, 1992, p. 308). From the consumers' point of view, materialism refers to the orientation towards the role of property and things in life, and it has three dimensions - success, self-orientation and happiness (Richins and Dawson, 1992). The material values are conceived as three domains: (1) the central place that the property holds in a person's life, (2) the belief that the acquiring property brings happiness and satisfaction with life, and (3) using property for making conclusions about one's own success or the success of other people (Cleveland et al., 2009).

Materialism can have a very significant impact on consumers' behaviour in general, as well as on their preferences. Theorists such as Holton (2000) and Ritzer (2007) suggests that materialism is especially implicated in consumption of global products, given global consumer culture's emphasis on selling dreams of affluence, personal success, and self-gratification. In particular, materialism has a positive impact on consumption that is reflected on the consumers' status, through 
a motivational process by which individuals try to improve their social position through the visible consumption of expensive products, such as cars, houses, gadgets and paintings (Eastman et al., 1997). Materialistically-oriented consumers strive to show their status and property in their relevant social groups. Purchasing and using imported luxury products indicates a higher level of material success and helps such consumers leave a positive impression on others (Kilbourne et al., 2005). Early research was focused on brand types which materialistically-oriented people prefer, including prestigious, luxury and global brands (Alden et al., 2006; Rindfleisch et al., 2009). This suggests that materialistic consumers recognize a greater value associated with global brands and that this perception will indirectly affect their attitudes towards these brands (Holt et al., 2004; Steenkamp et al., 2003).

Although materialism is a common feature of people around the world, differences in the socio-cultural and economic environment can affect the significance and importance of this feature in individual countries and cultures. In fact, in developing countries, consumers develop hedonistic attitudes, which, in consumption, are reflected through purchasing products which represent status symbols and conspicuous type of products (Belk, 1999). In these countries, the purchase and use of foreign products can be of great social significance from the perspective of consumers. Therefore, it can be noticed that materialism is gaining importance in developing countries, but it is losing importance in developed markets (Sharma, 2011).

The influence of materialism on consumers' attitudes towards global products has been investigated in numerous studies. In a study conducted by Sharma (2011), the positive influence that consumer materialism in developing countries has on the attitudes and intentions of consumers towards foreign and global products has been proven. Similar results were obtained in other studies (Alden et al., 2006; Cleveland et al., 2009; Alden et al., 2013; Holt et al., 2004; Rindfleisch et al., 2009; Steenkamp and Jong, 2010). On the other hand, there are not many studies which would confirm the negative impact that materialism has on consumers' attitudes and intentions in terms of purchasing local products and brands (Cleveland et al., 2009; Sharma, 2011). In accordance with the results of previous studies, materialism is expected to have positive impact on attitudes regarding purchase of global brands and negative on attitudes regarding purchase of local brands.

Country-of-origin effects have been the subject of research in the scientific literature for several decades. These effects imply that certain consumers exhibit positive or negative predispositions towards the purchase of various products, depending on the country of origin with which the products are associated (Verlegh and Steenkamp, 1999; Magnusson et al., 2011). In fact, many authors consider that the country of origin of products and its image influence positively or negatively 
consumers`attitudes regarding the products which originate from those countries, and this issue has been the subject of research of numerous studies (Chen et al., 2014; Costa et al., 2016; Herz and Diamantopoulos, 2017). Based on the analysis of relevant literature from this area, it can be concluded that the country of origin of products and services influences the attitudes and the behaviour of consumers concerning the purchase (Verlegh and Steenkamp, 1999; Pharr, 2005; Sharma, 2011).

In order to analyze drivers of consumers' attitudes, this research starts from the Theory of Social Identity (Tajfel, 1974, Tajfel and Turner, 1986), according to which individuals form their attitudes and behaviours in accordance with their belonging to a particular group. Based on this theory, the given factors can have a positive or negative impact on the attitudes and behaviour of consumers towards the inner group (in group), i.e. towards their country, as well as towards the outer group (out group), i.e. foreign countries.

For this research, some of the basic elements of the Theory of Reasoned ActionTRA (Ajzen and Fishbein, 1980), as well as of the Theory of Planned Behaviour - TPB (Ajzen, 1991) were used, according to which consumers` attitudes influence their behavioural intentions, and they ultimately affect the actual behaviour of consumers. Attitudes refer to positive or negative feelings (i.e. affective judgment) that a person has in relation to target behaviour (Fishbein and Ajzen, 1975, p. 216). In accordance with that, the consumer will likely perform a certain type of behaviour if it is assessed positively by him or her. Ajzen and Fishbein (1980) argue that intentions are largely influenced by individuals' attitudes and as the ultimate result of this, there is a response, and an action. Behavioural intentions can be defined as the strength of the individual's intention to perform a certain type of behaviour (Fishbein and Ajzen, 1975, p. 12). In this paper, the impact of behavioural intentions on the actual behaviour of customers in the process of purchasing local and global brands is analyzed. In accordance with the theoretical claims given above, we can expect that attitudes will have a positive impact on the behavioural intentions of consumers, and that intentions will ultimately lead to purchase of brands.

\section{Methodology}

In accordance with the literature review, Figure 1 presents a conceptual model of research which includes the relationships between analyzed variables. The model shows the influence that the variables of quality, prestige, ethnocentrism and materialism have on the attitudes of consumers. Furthermore, consumers' attitudes influence the intentions of consumers, which then affect the actual behaviour of consumers. 
Figure 1: Conceptual model of research

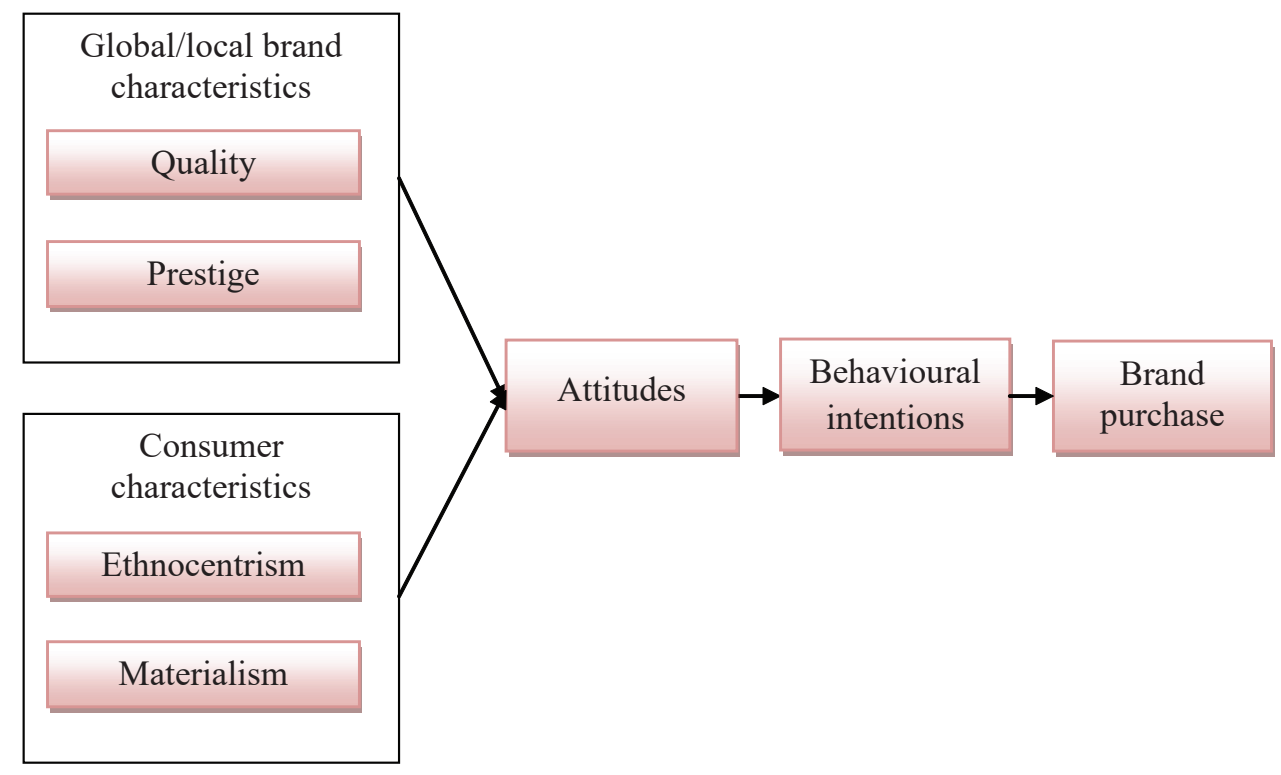

Source: Authors

The variables that were used in the research, as well as the statements within the variables, are shown in Table 1. The variables were taken and adapted from relevant scientific studies. In addition to variables related to ethnocentrism and materialism, the questionnaire also contained variables related to the quality and prestige of brands, attitudes, intentions and purchasing of brands, adapted for both global and local brands. In this way, it was possible to examine all relations for both types of brands that were observed. For both local and global brands, this study focused on the analysis of consumer attitudes and intentions towards brands in general, i.e. brands from different sectors. Additionally, for the purposes of this study, local brands were determined as Serbian brands, from different industries. Respondents were provided with examples of some of the well-known Serbian and global brands, at the beginning of questionnaire. 
Srđan Šapić et al. • Brand and consumer characteristics as drivers of behaviour...

Table 1: Measurement items

\begin{tabular}{|c|c|}
\hline Construct and items & References \\
\hline Quality & \multirow{5}{*}{$\begin{array}{l}\text { Zhou, Teng and } \\
\text { Poon (2008) }\end{array}$} \\
\hline Brand (global/local) has a very high quality image. & \\
\hline Brand (global/local) has a very high level of reliability. & \\
\hline Brand (global/local) is associated with the latest technology. & \\
\hline Brand (global/local) is associated with long-lasting quality. & \\
\hline Social prestige & \multirow{5}{*}{$\begin{array}{l}\text { Zhou, Teng and } \\
\text { Poon (2008) }\end{array}$} \\
\hline Brand (global/local) signifies one's trendy image. & \\
\hline Brand (global/local) represents the latest lifestyles. & \\
\hline Brand (global/local) symbolizes one's social image. & \\
\hline Brand (global/local) is associated with the symbol of prestige. & \\
\hline Ethnocentrism & \multirow{6}{*}{$\begin{array}{l}\text { Shimp and Sharma } \\
(1987)\end{array}$} \\
\hline $\begin{array}{l}\text { (Country) People should not buy foreign products, this hurts } \\
\text { domestic business and causes unemployment. }\end{array}$ & \\
\hline $\begin{array}{l}\text { It is not right to purchase foreign products, because this puts } \\
\text { (country) people out of jobs. }\end{array}$ & \\
\hline A real (citizen) should always buy domestic products. & \\
\hline I always prefer domestic products over foreign ones. & \\
\hline $\begin{array}{l}\text { We should purchase products manufactured in (country), instead of } \\
\text { letting other countries get rich off us. }\end{array}$ & \\
\hline Materialism & \multirow{5}{*}{ Richins (2004) } \\
\hline Buying things gives me a lot of pleasure. & \\
\hline My life would be better if I owned certain things that I do not. & \\
\hline I admire people who own expensive homes, cars, and clothes. & \\
\hline I would be happier if I could afford to buy more things. & \\
\hline Brand attitudes & \multirow{5}{*}{$\begin{array}{l}\text { Alden et al. (2006), } \\
\text { Herz and } \\
\text { Diamantopoulos } \\
(2017)\end{array}$} \\
\hline I think (global/local) brands are good. & \\
\hline I have a positive opinion of (global/local) brands. & \\
\hline I like (global/local) brands. & \\
\hline (Global/local) brands are satisfactory. & \\
\hline Behavioural intentions & \multirow{5}{*}{$\begin{array}{l}\text { Sharma (2011) } \\
\text { Herz and } \\
\text { Diamantopoulos } \\
(2017)\end{array}$} \\
\hline The likelihood that I purchase (global/local) brands is very high. & \\
\hline It's very likely that I will try (global/local) brands in the future. & \\
\hline In the future, I intend to purchase (global/local) brands. & \\
\hline I will strongly recommend to others to buy (global/local) brands. & \\
\hline Brand purchase & \multirow{3}{*}{$\begin{array}{l}\text { Dimofte et al. } \\
(2010)\end{array}$} \\
\hline I often choose (global/local) brands. & \\
\hline What percentage bought (global/local)? & \\
\hline
\end{tabular}

Source: Authors`calculation 
For this study, research was conducted in several districts of Central Serbia, in the period from the November 2017 until January 2018. Before commencing data collection, the questionnaire was initially tested on a smaller sample of 30 respondents. This preliminary testing was conducted in order to determine possible ambiguities in the questionnaire that could create confusion among the respondents, and in order to conduct preliminary tests of validity and reliability. After additional adaptations, the final version of the questionnaire was created. After preliminary testing, the researchers initiated the collection of questionnaires. Out of 360 respondents who agreed to participate in the study, 343 returned completed questionnaires to the interviewers. Following a review of the collected questionnaires, the researchers removed from further analysis 14 incomplete questionnaires. Thus, a total number of 329 questionnaires were used in the analysis. In addition, a convenience sample was used. The structure of the sample based on the socio-demographic characteristics is shown in Table 2. It can be noticed that most of the respondents in the sample are women (55.5\%). The highest percentage of respondents is members of the younger and middle generation, with secondary education.

Table 2: Demographic profile of respondents

\begin{tabular}{|l|l|c|}
\hline \multicolumn{2}{|l|}{ Division } & Percent (\%) \\
\hline \multirow{4}{*}{ Gender } & Male & 45.5 \\
\cline { 2 - 3 } & Female & 55.5 \\
\hline \multirow{5}{*}{ Education } & $18-24$ & 25.2 \\
\cline { 2 - 3 } & $25-34$ & 20.0 \\
\cline { 2 - 3 } & $35-44$ & 18.5 \\
\cline { 2 - 3 } & $45-54$ & 25.8 \\
\cline { 2 - 3 } & Over 55 & 10.5 \\
\hline \multirow{5}{*}{ Employment status } & Secondary education & 46.5 \\
\cline { 2 - 3 } & Undergraduate studies & 23.6 \\
\cline { 2 - 3 } & Graduate studies & 29.9 \\
\hline & Student & 22.8 \\
\cline { 2 - 3 } & Manager, entrepreneur & 10.1 \\
\cline { 2 - 3 } & Professor, doctor, engineer & 10.8 \\
\cline { 2 - 3 } & Office worker & 12.4 \\
\cline { 2 - 3 } & Worker & 27.1 \\
\cline { 2 - 3 } & Shop clerk & 9.1 \\
\cline { 2 - 3 } & Retired & 7.7 \\
\hline
\end{tabular}

Source: Authors`calculation 
The data was obtained by distributing questionnaires, with seven-point Likert scale statements (where the points are 1 - strongly disagree, 7- strongly agree). Statistical analysis of the data was performed using the software package SPSS (23.0) and the software AMOS (23). By using the confirmatory factor analysis, the convergent and discriminant validity of the suggested model was measured, through relevant indicators. After this analysis, using the structural equation modelling (SEM), the relationships between the variables in the observed model were analyzed. In this way, the testing of the hypothesis was performed.

\section{Empirical data and analysis}

Measurement of the model fit was tested by using the confirmatory factor analysis. In the case of an adequate model, the $\chi 2$ :df ratio is smaller than the threshold value of 3 recommended by Bagozzi and Yi (1988), GFI, IFI, TLI and CFI values should be over 0.9 (Byrne, 1998), whereas RMSEA value should be lower than 0.08 (Hair et al., 2006). The values of the fit indices are given in Table 3, which indicate the adequacy of observed model.

Table 3: Fit indices of the model

\begin{tabular}{|c|c|c|}
\hline Indicators & Measurement model & Recommended value \\
\hline$\chi^{2 / \mathrm{df}}$ & 2.525 & $<3$ \\
\hline GFI & 0.910 & $>0.9$ \\
\hline IFI & 0.923 & $>0.9$ \\
\hline TLI & 0.915 & $>0.9$ \\
\hline CFI & 0.922 & $>0.9$ \\
\hline RMSEA & 0.062 & $<0.08$ \\
\hline
\end{tabular}

Source: Authors`calculation

By analyzing the results of confirmatory factor analysis shown in the Table 4, it can be seen that all the values of the Average variance extracted - AVE are above the recommended value of 0.50 (Fornell and Larcker, 1981). This suggests the conclusion that the model meets the requirements for convergent validity. The values of the composite reliability (CR) of all the variables in the model have high values, and more accurately, higher than the recommended value of 0.7 (Fornell and Larcker, 1981). Based on the intercorrelation values between the variables and the values of the average variance extracted, it was determined that the AVE values for all the variables, are higher than the squared values of correlations of the given variables with other variables, which meets the requirements for the discriminant validity of the model. The analysis of the Cronbach's $\alpha$ determined that all the 
Srđan Šapić et al. • Brand and consumer characteristics as drivers of behaviour...

variables have the appropriate level of internal consistency, which is higher than 0.7 (Nunnally, 1978).

Table 4: Confirmatory factor analysis, Cronbach's $\alpha$ and descriptive statistics

\begin{tabular}{|l|c|c|c|c|c|c|}
\hline \multicolumn{1}{|c|}{ Factors and statements } & $\begin{array}{c}\text { Factor } \\
\text { loading }\end{array}$ & AVE & CR & $\alpha$ & M & SD \\
\hline Brand quality (Global) & & 0.565 & 0.835 & 0.823 & 4.821 & 1.187 \\
\hline Q_G_1 & 0.837 & & & & & \\
\hline Q_G_2 & 0.887 & & & & & \\
\hline Q_G_3 & 0.611 & & & & & \\
\hline Q_G_4 & 0.631 & & & & & \\
\hline Prestige (Global) & & 0.570 & 0.841 & 0.852 & 4.364 & 1.402 \\
\hline PR_G_1 & 0.758 & & & & & \\
\hline PR_G_2 & 0.818 & & & & & \\
\hline PR_G_3 & 0.776 & & & & & \\
\hline PR_G_4 & 0.659 & & & & & \\
\hline Brand quality (Local) & & 0.562 & 0.836 & 0.802 & 4.786 & 1.077 \\
\hline Q_L_1 & 0.787 & & & & & \\
\hline Q_L_2 & 0.823 & & & & & \\
\hline Q_L_3 & 0.685 & & & & & \\
\hline Q_L_4 & 0.695 & & & & & \\
\hline Prestige(Local) & & 0.715 & 0.909 & 0.911 & 3.763 & 1.529 \\
\hline PR_L_1 & 0.732 & & & & & \\
\hline PR_L_2 & 0.819 & & & & & \\
\hline PR_L_3 & 0.914 & & & & & \\
\hline PR_L_4 & 0.905 & & & & & \\
\hline Ethnocentrism & & 0.572 & 0.869 & 0.876 & 4.757 & 1.434 \\
\hline CET_1 & 0.696 & & & & & \\
\hline CET_2 & 0.762 & & & & & \\
\hline CET_3 & 0.836 & & & & & \\
\hline CET_4 & 0.726 & & & & & \\
\hline CET_5 & 0.755 & & & & & \\
\hline Materialism & 0.499 & & & & & \\
\hline MAT_1 & 0.908 & & & & & \\
\hline MAT_2 & 0.691 & & & & & \\
\hline MAT_3 & 0.842 & & & & & \\
\hline MAT_4 & & & & & \\
\hline
\end{tabular}


Srđan Šapić et al. • Brand and consumer characteristics as drivers of behaviour...

\begin{tabular}{|l|c|c|c|c|c|c|}
\hline \multicolumn{1}{|c|}{ Factors and statements } & $\begin{array}{c}\text { Factor } \\
\text { loading }\end{array}$ & AVE & CR & $\alpha$ & $\mathrm{M}$ & $\mathrm{SD}$ \\
\hline Attitudes (Global) & & 0.685 & 0.896 & 0.877 & 4.749 & 1.355 \\
\hline ATT_G_1 & 0.818 & & & & & \\
\hline ATT_G_2 & 0.899 & & & & & \\
\hline ATT_G_3 & 0.886 & & & & & \\
\hline ATT_G_4 & 0.692 & & & & & \\
\hline $\begin{array}{l}\text { Behavioural Intentions } \\
\text { (Global) }\end{array}$ & & 0.646 & 0.879 & 0.881 & 4.303 & 1.578 \\
\hline BI_G_1 & 0.835 & & & & & \\
\hline BI_G_2 & 0.867 & & & & & \\
\hline BI_G_3 & 0.797 & & & & & \\
\hline BI_G_4 & 0.707 & & & & & \\
\hline Attitudes (Local) & & 0.695 & 0.901 & 0.894 & 4.867 & 1.496 \\
\hline ATT_L_1 & 0.805 & & & & & \\
\hline ATT_L_2 & 0.903 & & & & & \\
\hline ATT_L_3 & 0.874 & & & & & \\
\hline ATT_L_4 & 0.744 & & & & & \\
\hline $\begin{array}{l}\text { Behavioural Intentions } \\
\text { (Local) }\end{array}$ & & 0.674 & 0.892 & 0.887 & 4.979 & 1.462 \\
\hline BI_L_1 & 0.861 & & & & & \\
\hline BI_L_2 & 0.868 & & & & & \\
\hline BI_L_3 & 0.782 & & & & & \\
\hline BI_L_4 & 0.768 & & & & & \\
\hline Purchase (Global) & & 0.625 & 0.769 & 0.764 & 4.812 & 1.441 \\
\hline PU_G_1 & 0.803 & & & & & \\
\hline PU_G_2 & 0.778 & & & & & \\
\hline Purchase (Local) & & 0.613 & 0.760 & 0.751 & 4.619 & 1.055 \\
\hline PU_L_1 & 0.760 & & & & & \\
\hline PU_L_2 & & & & & \\
\hline & & & & & \\
\hline
\end{tabular}

Source: Authors`calculation

Measurement model from the confirmatory factor analysis was turned into structural model, for the purpose of examining the relationships between the variables, following two step approach suggested by Diamantopoulos and Siguaw (2000). Structural equation modelling (SEM) was used to analyze relationships among the variables. Specifically, ten relations were tested, i.e. the strength and significance of direct effect of four independent variables on attitudes were determined. Results of this analysis are shown in the Table 5. 
Table 5: Testing of the relationships between variables (SEM)

\begin{tabular}{|c|c|c|}
\hline Relationships between variables & $\beta$ (S.E.) & $\mathrm{p}$ \\
\hline \multicolumn{3}{|l|}{ Brand quality } \\
\hline Brand quality (Local) $\rightarrow$ Attitudes (Local) & 0.499 & 0.000 \\
\hline Brand quality (Global) $\rightarrow$ Attitudes (Global) & 0.504 & 0.000 \\
\hline \multicolumn{3}{|l|}{ Prestige } \\
\hline Prestige (Local) $\rightarrow$ Attitudes (Local) & 0.054 & 0.189 \\
\hline Prestige (Global) $\rightarrow$ Attitudes (Global) & 0.275 & 0.009 \\
\hline \multicolumn{3}{|l|}{ Ethnocentrism } \\
\hline Ethnocentrism $\rightarrow$ Attitudes (Local) & 0.252 & 0.000 \\
\hline Ethnocentrism $\rightarrow$ Attitudes (Global) & -0.107 & 0.034 \\
\hline \multicolumn{3}{|l|}{ Materialism } \\
\hline Materialism $\rightarrow$ Attitudes (Local) & -0.042 & 0.398 \\
\hline Materialism $\rightarrow$ Attitudes (Global) & 0.158 & 0.000 \\
\hline \multicolumn{3}{|l|}{ Attitudes } \\
\hline Attitudes (Local) $\rightarrow$ Behavioural intentions (Local) & 0.657 & 0.000 \\
\hline Attitudes (Global) $\rightarrow$ Behavioural intentions (Global) & 0.639 & 0.000 \\
\hline \multicolumn{3}{|l|}{ Behavioural intentions } \\
\hline Behavioural intentions (Local) $\rightarrow$ Brand purchase (Local) & 0.767 & 0.000 \\
\hline Behavioural intentions (Global) $\rightarrow$ Brand purchase (Global) & 0.788 & 0.000 \\
\hline
\end{tabular}

Source: Authors`calculation

By observing the results in structural models, it can be concluded that variables which don't have significant impact on the consumers' attitudes regarding local brands are prestige and materialism. In the case of global brands, all variables have statistically significant impact on consumers`attitudes. More specifically, from a total of 10 tested effects, 8 of them appeared to be statistically significant.

\section{Results and discussion}

The aim of this research was to analyze factors which influence the formation of attitudes and intentions of consumers towards local and global brands. Specifically, the aim of the research was the analysis of the influence that the variables of brand quality and prestige, consumer materialism and ethnocentrism have on the attitudes with respect to local and global brands. The conducted analysis of antecedents of consumers' behaviour towards the purchase of local and global factors led to numerous results.

Quality has a positive and statistically significant impact on consumers' attitudes towards local $(\beta=0.499, p=0.000)$ and global brands $(\beta=0.504, p=0.000)$. Such 
results are in accordance with the results of previous studies, in which quality was proved to be strong predictor of consumers' attitudes and intentions regarding global brands (Swoboda and Hirschmann, 2016; Alden et al., 2006; Batra et al., 2000; Heinberg et al., 2016; Holt et al., 2004; Özsomer, 2012; Özsomer and Altaras, 2008; Steenkamp et al., 2003; Dimofte et al., 2010; Kumar et al., 2009; Zhou and Wong, 2008), and local ones (Özsomer, 2012). These findings imply that quality is important antecedent of consumer behaviour in the case of both types of brands, which implies that performances, reliability and technology of brands are key drivers of consumers' decisions regarding purchase of brands.

On the other hand, the prestige of local brands doesn't have significant impact on consumers' attitudes $(\beta=0.054, p=0.189)$, whereas the prestige of global brands has a positive and statistically significant impact on consumers' attitudes towards purchase of this type of brand $(\beta=0.275, p=0.009)$. Having in mind that the prestige of local brands has a very low average rating, compared to prestige of global ones $\left(\mathrm{M}_{\text {Local }}=3.763, \mathrm{SD}_{\text {Local }}=1.529: \mathrm{M}_{\text {Global }}=4.364, \mathrm{SD}_{\text {Global }}=1.402\right)$, it can be concluded that consumers do not perceive local brands as a prestigious alternative compared to global ones. These findings support results of previous studies, where prestige of global brands is significant determinant of consumer behaviour (Özsomer, 2012; Ger, 1999; Steenkamp et al., 2003; Holt et al., 2004; Zhou and Belk, 2004). Furthermore, our study supports findings which indicate that influence of prestige of global brands on consumers`attitudes is particularly pronounced in developing countries, in which consumers perceive brands from Western countries as symbols of prestige and status (Batra et al., 2000; Coulter et al., 2003). A reason for that is the fact that consumers think that there is a symbolic connection between global brands and economic centres of the worlds (of the most developed countries) from which these brands originate, and that by purchasing these brands they want to acquire the lifestyle of consumers from these parts of the world (Alden et al., 2006; Özsomer, 2012).

Ethnocentrism has a positive and statistically significant effect on consumers' attitudes towards local brands $(\beta=0.252, p=0.000)$. This relationship has been previously established in scientific literature (Balabanis and Diamantopoulos, 2004; Josiassen, 2011; Strizhakova and Coulter, 2015; Verlegh, 2007; Cleveland et al., 2009; Siamagka and Balabanis, 2015; Klein et al., 2006; Sharma, 2011). In that manner, our study provides support for this relationship. On the other side, ethnocentrism has negative, statistically significant effect on consumers' attitudes towards global brands $(\beta=-0.107, p=0.034)$. These results coincide with results of previous studies (Oberecker and Diamantopoulos, 2011; Shimp and Sharma, 1987; Verlegh, 2007; Klein, 2002; Klein et al., 2006; Cleveland et al., 2009; Sharma, 2011; Siamagka and Balabanis, 2015).

Materialism has a positive and statistically significant impact on consumers' attitudes towards global brands $(\beta=0.158 \mathrm{p}=0.000)$, whereas it has a negative 
but not statistically significant impact on consumers' attitudes towards local brands $(\beta=-0.042, p=0.398)$. Positive impact of materialism on attitudes towards global brands has been proven in previous studies (Alden et al., 2006; Cleveland et al., 2009; Alden et al., 2013; Holt et al., 2004; Rindfleisch et al., 2009; Steenkamp and Jong, 2010). Thus, our study provides support for this relationship. This suggests that materialistically-oriented consumers associate high value with global brands and that this perception can positively affect their attitude towards these brands. Bearing in mind that Serbia is developing country, our results are in accordance with findings which indicate that materialistically-oriented consumers in these countries will attribute more importance to foreign and imported products from developed countries, as they will have a positive impact on their social status (Sharma, 2011).

Consumers' attitudes have a very strong, positive and statistically significant effect on the intentions of consumers towards future purchases, when it comes to both local and global brands $(\beta=0.657, p=0.000$ in the case of local; $\beta=0.639, p$ $=0.000$ in the case of global ones). These results confirm the justification of application of the Theory of Reasoned Action. Finally, consumers' intentions also have a very strong, positive and statistically significant impact on the actual purchase of brands, which confirms the connection between intentions and actual behaviour. $(\beta=0.767, p=0.000$ in the case of local; $\beta=0.788, p=0.000$ in the case of global ones). Such results are in accordance with the results of numerous previous studies, where a positive link between the attitudes, intentions of consumers and their purchase was confirmed (Zeugner-Roth et al., 2015; Riefler, 2012; Herz and Diamantopoulos, 2017; Balabanis and Diamantopoulos, 2011).

The results of the conducted research that are given above can have a scientific and practical contribution. With regard to the theoretical implications of this research, this paper has contributed to current studies related to the purchase of global and local brands, and determinants of this behavior. Starting from Theory of planned behaviour and Theory of social identity, several antecedents were researched in proposed model, thus providing new insights into consumer behaviour in international context, focusing on the consumer-brand relationship aspect. The main contribution of the research lies in understanding the impact of the quality and prestige of brands, materialism and ethnocentrism on attitudes regarding local and global brands, which ultimately lead to purchase behaviour. Furthermore, this contribution is especially pronounced in terms of emerging markets, such as Serbian and markets of Western Balkan, since studies concerning this scientific field are scarce.

The results of the research provide a contribution in terms of their practical application. Namely, having in mind that there is very pronounced competition among local and global companies in a large number of products and service categories (generally speaking) in almost every country, it is very important to understand consumers' attitudes and preferences when choosing brands in the purchasing process. 
For the marketing managers of local and global companies it is of great importance to understand the way consumers perceive the quality and prestige of local and global brands, as well as the way in which these perceptions affect their decisions to buy those brands. In this way, global brand managers can develop and invest in quality and prestige aspects of brands, to create positioning strategies and differential advantage on the market, compared to local brands. Results of the study clearly indicate that by creating and communicating these aspects can ensure consumer preference for global brands. On the other side, local brands are perceived as less prestigious alternative to global ones, which indicates that local brand managers should invest in development of prestige aspects of brands. This strategy can be useful in circumstances when local companies are facing fierce competition from global companies, which is present in the case of Serbian market. Such aspects of brands can be developed by enhancing aspects of uniqueness and local iconness, as suggested by Steenkamp et al. (2003). Furthermore, it is very important to understand the degree of ethnocentrism and materialism that consumers possess in the country where companies operate and to what extent these consumer characteristics influence the choice of local and global brands. These findings are important in the process of segmentation and targeting of selected segments. Marketing managers need to understand consumer sentiment related to the ethnocentrism in their markets of interest, and incorporate it in their promotional efforts. Additionally, local brand managers can attract consumers with materialistic orientation, by emphasizing prestige and symbolic aspects of brands, thus satisfying their taste and needs.

\section{Conclusion}

The main objective of the paper was to analyze the impact of brand and consumer characteristics on consumers' behaviour towards the purchase of local and global brands. Through the conceptual model, we have attempted to include factors that may have a significant impact on attitudes, intentions and ultimately, behaviour of consumers. In general, the results of the research have indicated that the brand quality, prestige, materialism and ethnocentrism have statistically significant impact on consumers' attitudes regarding local and global brands. Brand quality has positive impact on attitudes towards global and local brands, whereas prestige has positive impact on attitudes towards global brands and insignificant impact on attitudes regarding local brands. Additionally, ethnocentrism has a positive impact on attitudes concerning local brands, and negative on attitudes towards global brands. Conversely, materialism has a positive impact on attitudes about global brands, but statistically insignificant impact on attitudes about local brands. Furthermore, attitudes have strong and significant impact on behavioural intentions, and intentions have strong influence on actual purchase of both types of brands. These findings imply that the main hypothesis of the paper is proven and that brand 
and consumer characteristics are significant predictors of consumer behaviour towards purchase of local and global brands.

The conducted research has certain limitations as well. The primary limitation refers to the number of factors included in the conceptual model of the research. Namely, the research model encompasses the quality of brands, prestige, consumer ethnocentrism and consumer materialism, as determinants of consumer behaviour. However, other relevant factors can be found in relevant scientific literature, whose influence on the attitudes and intentions of consumers, such as patriotism, cosmopolitanism, brand prices, consumers' travels, corporate social responsibility, and others - is still being investigated. In future research it would be useful to include additional variables in the model of the research in order to increase the percentage of variances that the model explains, which would better explain the attitudes and intentions of the consumers. Also, an important limitation of the research relates to the fact that it was carried out in the territory of Central Serbia, which did not include other regions of the Republic of Serbia. It would be useful to include respondents from other cities and regions, as well as international respondents, in future research, in order to increase the generalization of the obtained research results. Finally, in the future research, it would be useful to analyse differences among the attitudes of the respondents from different demographic groups, which can be helpful for domestic and foreign companies when selecting target segments in their appearance in the selected markets and when creating different marketing strategies.

\section{References}

Ajzen, I. (1991) “The theory of planned behaviour", Organizational Behaviour and Human Decision Processes, Vol. 50, No. 2, pp. 179-211, doi: 10.1016/07495978(91)90020-T.

Ajzen, I., Fishbein, M. (1980) Understanding attitudes and predicting social behaviour, Englewood Cliffs, NJ: Prentice-Hall.

Alden, D. L., et al. (2013) “The Effect of Global Company Animosity on Global Brand Attitudes in Emerging and Developed Markets: Does Perceived Value Matter?", Journal of International Marketing, Vol. 21, No. 2, pp. 17-38, doi: 10.1509/jim.12.0086.

Alden, L.D., Steenkamp, J-B. E.M., Batra, R. (2006) "Consumer attitudes toward marketplace globalization: structure, antecedents and consequences", International Journal of Research in Marketing, Vol. 23, No. 3, pp. 227-239, doi: 10.1016/j. ijresmar.2006.01.010.

Bagozzi, R.P., Yi, Y. (1988) "On the evaluation of structural equation model", Journal of Academy of Marketing Science, Vol. 16, No. 1, pp. 74-94, doi: 10.1177/ 009207038801600107. 
Balabanis, G., Diamantopoulos, A. (2004) "Domestic Country Bias, Country-ofOrigin Effects, and Consumer Ethnocentrism: A Multidimensional Unfolding Approach", Journal of the Academy of Marketing Science, Vol. 32, No. 1, pp. 80-95, doi: 10.1177/0092070303257644.

Balabanis, G., Diamantopoulos, A. (2011) "Gains and Losses from the Misperception of Brand Origin: The Role of Brand Strength and Country-ofOrigin Image", Journal of International Marketing, Vol. 19, No. 2, pp. 95-116, doi: 10.1509/jimk.19.2.95.

Batra, R., et al. (2000) "Effects of brand local/nonlocal origin on consumer attitudes in developing countries", Journal of Consumer Psychology, Vol. 9, No. 2, pp. 83-95, doi: 10.1207/s15327663jcp0902_3.

Batra, R., Sinha, I. (2000) "Consumer-Level Factors Moderating the Success of Private Label Brands", Journal of Retailing, Vol. 76, No. 2, pp. 175-191, doi: 10.1016/s0022-4359(00)00027-0.

Belk, R. W. (1999) "Leaping Luxuries and Transitional Consumers", in Rajeev Batra (Ed.), Marketing Issues in Transition Economies, Boston: Kluwer Academic Press, pp. 41-54, doi: 10.1007/978-1-4615-5009-9_2.

Belk, R. W., Paun, M. (1993) "Ethnicity and Consumption in Romania" in The Global and the Local, Consumption and European Identity, Amsterdam: SISWO, Vol. 3, pp. 1-38.

Byrne, B. M. (1998) Structural Equation Modeling with LISREL, PRELIS, and SIMPLIS: Basic Concepts, Applications, and Programming, Lawrence Erlbaum, Hillsdale, NJ: Psychology Press.

Chen, C. Y., Mathur, P., Maheswaran, D. (2014) "The effects of country-related affect on product evaluations", Journal of Consumer Research, Vol. 41, No. 4, pp. 1033-1046, doi: 10.1086/678194.

Cleveland, M., Laroche, M., Papadopoulos, N. (2009) "Cosmopolitanism, Consumer Ethnocentrism, and Materialism: An Eight-Country Study of Antecedents and Outcomes”, Journal of International Marketing, Vol. 17, No. 1, pp. 116-146, doi: 10.1509/jimk.17.1.116.

Costa, C., Carneiro, J., Goldszmidt, R. (2016) "A contingent approach to countryof-origin effects on foreign products evaluation: Interaction of facets of country image with product classes", International Business Review, Vol. 25, No. 5, pp. 1066-1075, doi: 10.1016/j.ibusrev.2016.01.003.

Coulter, R. A., Price, L. L., Feick, L. (2003) "Rethinking the origins of product involvement, involvement with branded products, and brand commitment: Women and cosmetics in postsocialist Central Europe", Journal of Consumer Research, Vol. 30, No. 2, pp. 151-169, doi: 10.1086/376809.

Crane, D. (2002). Culture globalization. In Crane, D., Kawashima, N., Kawasaki, K. (Eds.), Global culture: Media, arts, policy and globalization, New York: Routledge, pp. 1-25, doi: 10.4324/9781315538792. 
Diamantopoulos, A., Siguaw, J. (2000) Introducing LISREL, London: SAGE Publications.

Dimofte, C. V., Johannson, J. K., Ronkainen, I.A. (2008) "Cognitive and Affective Reactions of U.S. Consumers to Global Brands", Journal of International Marketing, Vol. 16, No. 4, pp. 113-135, doi: 10.1509/jimk.16.4.113.

Dimofte, C. V., Johansson, J. K., Bagozzi, R. P. (2010) "Global Brands in the United States: How Consumer Ethnicity Mediates the Global Brand Effect", Journal of International Marketing, Vol. 18, No. 3, pp. 81-106. doi: 10.1509/jimk.18.3.81.

Eastman, J. K., et al. (1997) "The Relationship Between Status Consumption and Materialism: A Cross-cultural Comparison of Chinese, Mexican, and American Students", Journal of Marketing Theory and Practice, Vol. 5, No. 1, pp. 52-66, doi: 10.1080/10696679.1997.11501750.

Erdem, T., Swait, J., Valenzuela, A. (2006) "Brands as Signals: A Cross-Country Validation Study", Journal of Marketing, Vol. 70, No.1, pp. 34-49, doi: 10.1509/jmkg.2006.70.1.34.

Fishbein M., Ajzen, I. (1975) Belief, attitude, intention and behaviour: an introduction to theory and research. Boston: Reading. Addison-Wesley.

Fornell, C. Larcker, D. F. (1981) "Evaluating structural equation models with unobservable variables and measurement error", Journal of Marketing Research, Vol. 18, No. 1, pp. 39-50, doi: 10.2307/3151312.

Friedman, J. (1990) "Being in the world: globalization and localization", Theory, Culture and Society, Vol. 7, No. 2-3, pp. 311-328, doi: 10.1177/ 026327690007002018.

Ger, G. (1999) "Localizing in the Global Village: Local Firms Competing in Global Markets", California Management Review, Vol. 41, No. 4, pp. 64-83, doi: 10.2307/41166010.

Guo, X. (2013) "Living in a Global World: Influence of Consumer Global Orientation on Attitudes Toward Global Brands from Developed Versus Emerging Countries", Journal of International Marketing, Vol. 21, No. 1, pp. 1-22, doi: 10.1509/jim.12.0065.

Gurhan-Canli, Z., Sarial-Abi, G. and Hayran, C. (2018) "Consumers and Brands Across the Globe: Research Synthesis and New Directions", Journal of International Marketing, Vol. 26, No. 1, pp. 96-117, doi: 10.1509/jim.17.0063.

Hair, J.F., et al. (2006) Multivariate Data Analysis. 6th ed., Upper Saddle River, NJ: Prentice Hall.

Heinberg, M., Ozkaya, H., and Taube, M. (2016) "A brand built on sand: Is acquiring a local brand in an emerging market an ill-advised strategy for foreign companies?", Journal of the Academy of Marketing Science, Vol. 44, No. 5, pp. 586-607, doi: 10.1007/s11747-015-0452-7. 
Herz, M., Diamantopoulos, A. (2017) “I Use It but Will Tell You That I Don't: Consumers' Country-of-Origin Cue Usage Denial", Journal of International Marketing, Vol. 25, No. 2, pp. 52-71, doi: 10.1509/jim.16.0051.

Hofstede, G., Hofstede, G. J., Minkov, M. (2010) Cultures and Organizations, Software in Mind, New York: McGraw Hill.

Holt, D. B. (2002) "Why Do Brands Cause Trouble? A Dialectical Theory of Consumer Culture and Branding", Journal of Consumer Research, Vol. 29, No. 1, pp. 70-90, doi: 10.1086/339922.

Holt, D. B., Quelch, J.A., Taylor, E.L. (2004) "How Global Brands Compete", Harvard Business Review, Vol. 82, No. 9, pp. 68-75.

Holton, R. (2000) "Globalization's Cultural Consequences", Annals of the American Academy of Political and Social Science, Vol. 570, No. 1, pp. 140-152, doi: 10.1177/000271620057000111.

Josiassen, A. (2011) "Consumer Disidentification and Its Effects on Domestic Product Purchases: An Empirical Investigation in the Netherlands", Journal of Marketing, Vol. 75, No. 2, pp. 124-140, doi: 10.1509/jmkg.75.2.124.

Kapferer, J-N. (1997) Strategic Brand Management, 2nd edn, Dover, NH: Kogan Page.

Keillor, B. D., D’Amico, M., Horton, V. (2001) "Global consumer tendencies", Psychology and Marketing, Vol. 18, No. 1, pp. 1-19, doi: 10.1002/1520-6793 (200101)18:1<1::aid-mar1>3.0.co;2-u.

Keller, K.L. (1998) Strategic Brand Management: Building, Measuring, and Managing Brand Equity, Upper Saddle River, NJ: Prentice-Hall.

Kilbourne, W., Grünhagen, M., Foley, J. (2005) "A cross-cultural examination of the relationship between materialism and individual values", Journal of Economic Psychology, Vol. 26, No. 5, pp. 624-641, doi: 10.1016/j.joep.2004. 12.009 .

Klein, J. C, Ettenson, R., Krishnan, B. C. (2006) "Extending the construct of consumer ethnocentrism: When foreign products are preferred", International Marketing Review, Vol. 23, No. 3, pp. 304-321, doi: 10.1108/02651330610670460.

Klein, J. G. (2002) "Us versus Them, or Us versus Everyone? Delineating Consumer Aversion to Foreign Goods", Journal of International Business Studies, Vol. 33, No. 2, pp. 345-363, doi: 10.1057/palgrave.jibs.8491020.

Kumar, A., Lee, H-J., Kim, Y-K. (2009) "Indian Consumers' Purchase Intention Toward a United States Versus Local Brand", Journal of Business Research, Vol. 62, No. 5, pp. 521-527, doi: 10.1016/j.jbusres.2008.06.018 .

Kunda, Z. (1999) Social Cognition: Making Sense of People. Cambridge, MA: MIT Press.

Levitt, T. (1983) "The globalization of markets”, Harvard Business Review, Vol.61, No. 3, pp. 39-49. 
Magnusson, P., Westjohn, S., Zdravkovic, S. (2011) "What? I thought Samsung was Japanese: accurate or not, perceived country of origin matters", International Marketing Review, Vol. 28, No. 5, pp. 454-472, doi: 10.1108/02651331111167589.

Marinković, V., Stanišić, N., Kostić, M. (2011) "Potrošački etnocentrizam građana Srbije", Sociologija, Vol. 53, No. 1, pp. 43-58, doi: 10.2298/SOC1101043M.

Netemeyer, R. G., Durvasula, S., Lichtenstein, D. R. (1991) "A Cross-National Assessment of the Reliability and Validity of the CETSCALE", Journal of Marketing Research (JMR), Vol. 28, No. 3, pp. 320-327, doi: 10.2307/3172867.

Nijssen, E. J., Douglas, S. P. (2011) “Consumer World-Mindedness and Attitudes Toward Product Positioning in Advertising: An Examination of Global Versus Foreign Versus Local Positioning", Journal of International Marketing, Vol. 19, No. 3, pp. 113-133, doi: 10.1509/jimk.19.3.113.

Nunnally, J.C. (1978) Introduction to Psychological Measurement, New York: McGraw-Hill.

Oberecker, E. M., Diamantopoulos, A. (2011) "Consumers' Emotional Bonds with Foreign Countries: Does Consumer Affinity Affect Behavioural Intentions?", Journal of International Marketing, Vol. 19, No. 2, pp. 45-72, doi: 10.1509/ jimk.19.2.45.

Özsomer, A. (2012) "The Interplay Between Global and Local Brands: A Closer Look at Perceived Brand Globalness and Local Iconness", Journal of International Marketing, Vol. 20, No. 2, pp. 72-95, doi: 10.1509/jim.11.0105.

Özsomer, A., Altaras, S. (2008) "Global Brand Purchase Likelihood: A Critical Synthesis and an Integrated Conceptual Framework" Journal of International Marketing, Vol. 16, No. 4, pp. 1-28, doi: 10.1509/jimk.16.4.1.

Pharr, J.M. (2005) "Synthesizing country-of-origin research from the last decade: is the concept still salient in an era of global brands?", Journal of Marketing Theory and Practice, Vol. 13, No. 4, pp. 34-45, doi: 10.1080/10696679.2005. 11658557.

Richins, M. L. (2004) "The material values scale: Measurement properties and development of a short form", Journal of Consumer Research, Vol. 31, No. 1, pp. 209-219, doi: 10.1086/383436.

Richins, M. L., Dawson, S. (1992) "A consumer values orientation for materialism and its measurement: Scale development and validation", Journal of Consumer Research, Vol. 19, No. 3, pp. 303-316, doi: 10.1086/209304 .

Riefler, P. (2012) "Why consumers do (not) like global brands: The role of globalization attitude, GCO and global brand origin", International Journal of Research In Marketing, Vol. 29, No. 1, pp. 25-34, doi: 10.1016/j.jiresmar.2011.11.001.

Rindfleisch, A., Burroughs, J.E., Wong, N. (2009) "The Safety of Objects: Materialism, Existential Insecurity, and Brand Connection", Journal of Consumer Research, Vol. 36, No. 1, pp. 1-16, doi: 10.1086/595718. 
Ritzer, G. (2007) The Globalization of Nothing 2, Thousand Oaks, CA: Pine Forge Press.

Schuiling, I., Kapferer, J-N. (2004) "Executive Insights: Real Differences Between Local and International Brands: Strategic Implications for International Marketers", Journal of International Marketing, Vol. 12, No. 4, pp. 97-112, doi: 10.1509/jimk.12.4.97.53217.

Sharma, P. (2011) "Country of Origin Effects in Developed and Emerging Markets: Exploring the Contrasting Roles of Materialism and Value Consciousness", Journal of International Business Studies, Vol. 42, No. 2, pp. 285-306, doi: 10.1057/jibs.2010.16.

Shimp, T.A., Sharma, S. (1987) "Consumer ethnocentrism: construction and validation of the CETSCALE", Journal of Marketing Research, Vol. 24, No. 3, pp. 280-289, doi: 10.2307/3151638.

Siamagka, N-T., Balabanis, G. (2015) "Revisiting Consumer Ethnocentrism: Review, Reconceptualization, and Empirical Testing", Journal of International Marketing, Vol. 23, No. 3, pp. 66-86, doi: 10.1509/jim.15.0085.

Steenkamp, J. E., de Jong, M. G. (2010) "A Global Investigation into the Constellation of Consumer Attitudes Toward Global and Local Products", Journal of Marketing, Vol. 74, No. 6, pp. 18-40, doi: 10.1509/jmkg.74.6.18.

Steenkamp, J.B.E.M., Batra, R., Alden, D. L. (2003) "How perceived brand globalness creates brand value", Journal of International Business Studies, Vol. 34, No. 1, pp. 53-65, doi: 10.1057/palgrave.jibs. 8400002.

Strizhakova, Y., Coulter, R. A. (2015) "Drivers of Local Relative to Global Brand Purchases: A Contingency Approach", Journal of International Marketing, Vol. 23, No. 1, pp. 1-22, doi: 10.1509/jim.14.0037.

Strizhakova, Y., Coulter, R.A., Price, L. L. (2008) "The Meanings of Branded Products: A Cross-National Scale Development and Meaning Assessment", International Journal of Research in Marketing, Vol. 25, No. 2, pp. 82-93, doi: 10.1016/j.ijresmar.2008.01.001.

Strizhakova, Y., Coulter, R.A., Price, L. L. (2011) "Branding in a Global Marketplace: The Mediating Effects of Quality and Self- Identity Brand Signals", International Journal of Research in Marketing, Vol. 28, No. 4, pp. 342-351, doi: 10.1016/j.ijresmar.2011.05.007.

Supphellen, M., Rittenburg T. L. (2001) "Consumer Ethnocentrism: When Foreign Products Are Better”, Psychology and Marketing, Vol. 18, No. 9, pp. 907-927, doi: 10.1002/mar.1035.

Swoboda, B., Hirschmann, J. (2016) "Does Being Perceived as Global Pay Off? An Analysis of Leading Foreign and Domestic Multinational Corporations in India, Japan, and the United States", Journal of International Marketing, Vol. 24, No. 3, pp. 1-30, doi: 10.1509/jim.15.0088. 
Tajfel, H. (1974) "Social identity and intergroup behaviour", Social Science Information, Vol. 13, No. 2, pp. 65-93, doi: 10.1177/053901847401300204.

Tajfel, H., Turner, J. C. (1986) "The social identity theory of intergroup behaviour", In S. Worchel and W. G. Austin (Eds.), The psychology of intergroup relations, pp. 7-24. Chicago: Nelson-Hall.

Thompson, C. J., Tambyah, S. K. (1999) "Trying to Be Cosmopolitan", Journal of Consumer Research, Vol. 26, No. 3, pp. 214-241, doi: 10.1086/209560.

Verlegh, P.W.J. (2007) "Home Country Bias in Product Evaluation: The Complementary Roles of Economic and Socio-Psychological Motives", Journal of International Business Studies, Vol. 38, No. 3, pp. 361-373, doi: 10.1057/ palgrave.jibs. 8400269 .

Verlegh, P.W.J., Steenkamp, J.-B.E.M., (1999) "A review and meta-analysis of country-of-origin research", Journal of Economic Psychology, Vol. 20, No. 5, pp. 521-546, doi: 10.1016/s0167-4870(99)00023-9.

Xie, Y., Batra, R., Peng, S. (2015) “An extended model preference formation between global and local brands: the roles of identity expressiveness, trust, and affect", Journal of International Marketing, Vol. 23, No. 1, pp. 50-71, doi: 10.1509/jim.14.0009.

Yip, G., Hult, G.T.M. (2012) Total Global Strategy, 3rd ed., Boston, MA: Pearson.

Zeugner-Roth, K. P., Žabkar, V., Diamantopoulos, A. (2015) "Consumer ethnocentrism, national identity, and consumer cosmopolitanism as drivers of consumer behaviour: a social identity theory perspective", Journal of International Marketing, Vol. 23, No. 2, pp. 25-54, doi: 10.1509/jim.14.0038.

Zhou, L., Teng, L., Poon, P. (2008) "Susceptibility to global consumer culture: A three-dimensional scale", Psychology and Marketing, Vol. 25, No. 4, pp. 336351, doi: 10.1002/mar.20212.

Zhou, L., Wong, A. (2008) "Exploring the influence of product conspicuousness and social compliance on purchasing motives of young Chinese consumers for foreign brands", Journal of Consumer Behaviour, Vol. 7, No. 6, pp. 470-483, doi: 10.1002/cb.265.

Zhou, N., Belk, R. W. (2004) "Chinese Consumer Readings Of Global And Local Advertising Appeals", Journal of Advertising, Vol. 33, No. 3, pp. 63-76, doi: 10.1080/00913367.2004.10639169. 


\title{
Brand i karakteristike potrošača kao pokretača ponašanja prema globalnim i lokalnim brandovima
}

\author{
Srđan Šapić ${ }^{1}$, Milan Kocić ${ }^{2}$ Jovana Filipovic ${ }^{3}$
}

\begin{abstract}
Sažetak
Glavna svrha ovog istraživanja je utvrditi kako utjecaj branda i karakteristika potrošača na ponašanje potrošača pri odabiru globalnih i lokalnih brandova. Polazeći od teorije planiranog ponašanja i teorije društvenog identiteta, istraženo je nekoliko preduvjeta stavova potrošača u predloženom modelu - kvaliteta robnih marki, prestiž, etnocentrizam i materijalizam. U tu svrhu prikupljeno je 329 ispitanika. Konfirmatorna faktorska analiza korištena je za testiranje valjanosti modela i modeliranje strukturalne jednadžbe (SEM) za određivanje odnosa između varijabli. Empirijska istraživanja pokazala su da čimbenici kvalitete lokalnih brandova i etnocentrizma imaju pozitivan i statistički značajan utjecaj na stavove potrošača prema lokalnim brandovima. S druge strane, kvaliteta robne marke, prestiž $i$ materijalizam imaju pozitivan učinak na stavove potrošača prema globalnim brandovima, dok etnocentrizam negativno utječe na stavove prema ovakvim vrstama marki. Nadalje, istraživanje je pokazalo da stavovi imaju pozitivan utjecaj na bihevioralnu namjeru potrošača u vezi s kupnjom lokalnih $i$ svjetskih marki te da namjere potrošača imaju pozitivan učinak na stvarnu kupnju obje vrste marki. Glavni nalaz ovog istraživanja upućuje na to da karakteristike potrošača i marki utječu na ponašanje potrošača u smislu nabave gore spomenutih vrsta marki. Provedeno istraživanje ima znanstveni $i$ praktičan doprinos $u$ prikupljenim informacijama o čimbenicima koji utječu na odluke potrošača o kupnji lokalnih i svjetskih marki.
\end{abstract}

Ključne riječi: globalni brand, lokalni brand, kvaliteta robne marke, prestiž, materijalizam, etnocentrizam, stavovi i namjere potrošača

JEL klasifikacija: M31

1 Izvanredni profesor, Ekonomski fakultet, Sveučilište u Kragujevcu, Liceja Kneževine Srbije 3, 34000 Kragujevac, Srbija. Znanstveni interes: međunarodni marketing, međunarodno poslovanje.Tel.:+38134303 575.Fax:+38134303 516.E-mail: ssapic@kg.ac.rs. Osobna web stranica: $h t t p: / / w w w . e k f a k . k g . a c . r s / e n / t e a c h i n g-s t u f f ? i d=366 \& i d d=268$.

${ }^{2}$ Izvanredni profesor, Ekonomski fakultet, Sveučilište u Kragujevcu, Liceja Kneževine Srbije 3, 34000 Kragujevac, Srbija. Znanstveni interes: marketing. Tel.: +38134303 538. Fax: +381 34303 516. E-mail: mkocic@kg.ac.rs. Osobna web stranica: http://www.ekfak.kg.ac.rs/en/ teaching-stuff? id $=366 \&$ idd $=199$.

${ }^{3}$ Asistent, doktorand, Ekonomski fakultet, Sveučilište u Kragujevcu, Liceja Kneževine Srbije 3, 34000 Kragujevac, Srbija. Znanstveni interes: međunarodni marketing, međunarodno poslovanje. Tel.: +38134303 530. Fax: +38134303 516. E-mail: jovanagolo@kg.ac.rs. Osobna web stranica: http://www.ekfak.kg.ac.rs/en/teaching-stuff?id=366\&idd=398 (osoba za kontakt). 